\title{
Mencari Tolok Ukur Eksistensi Hak Ulayat atas Tanah Menurut UUD 45
}

\author{
Winahyu Erwiningsih
}

\begin{abstract}
Democracy highly upholds respective principle of customary law society in general and traditional indegenous agrarian rights in particular. This principle should be elaborated firmly in regulations in order to avoid power abuse inward customary law community. Local govemment should not hesitate to provide traditional indegenous agrarian rights in listed form to avoid consession objectivism of forest management by private sector. Local govermment should also had courage to initate the establishement of custom deliberation institution as its partner and seek mutual benefited solution when public interests of traditional indigenous soil use as development object.
\end{abstract}

\section{Pendahuluan}

Indonesia adalah Negara kepulauan, didiami lebih dari dua ratus juta penduduk. Dilihat dari perbedaan bahasa, sistem sosial dan budaya terbagi dalam lebih dari 300 suku bangsa. C Van Vollenhoven berdasarkan analisis ciri-ciri sistem hukum yang berlaku secara hipotesis membedakan dalam 19 lingkungan hukum adat.' Banyaknya lingkungan masyarakat adat mendiskripsikan bahwa sebagian besar masyarakat Indonesia bersifat majemuk dengan struktur sosial dan budaya sederhana. Fakta demikian sebagai bagian dari keanekaragaman ekspresi pola kehidupan sosial budaya yang mereka pilih dan bagian dari kekayaan bangsa Indonesia. Perubahan kedua UUD 45, khususnye Pasal 18 (ayat 4) menyatakan bahwa Negare mengakui dan menghormati kesatuan. kesatuan masyarakat hukum adat beserta hak. hak tradisionalnya dengan syarat sepanjanç kenyataannya masih hidup, sesuai dengar perkembangan masyarakat dan prinsi Negara Kesatuan Republik Indonesia.

Dari ketentuan tersebut, dapa diketengahkan persoalan: Apakah yan! dimaksud dengan masyarakat hukum ada itu? Apa yang dimaksud sepanjan! kenyataannya masih hidup atau sepanjan!

\footnotetext{
'C. Van Vollenhoven, Het Adatrech Van Nederlands Indie, Jilid 1 bagian 1 tahun 1925, (TTp:Tp, 1925)
} 
kenyataannya masih ada? Apa yang dimaksud sepanjang kenyataannya masih hidup atau sepanjang kenyataannya masih ada? Siapakah orang atau badan yang berwenang menetapkan hidup matinya masyarakat hukum adat? Tolok ukur apakah yang dipakai untuk menentukan? Bagaimana kedudukan hàk ulayat atas tanah berkaitan dengan eksistensi masyarakat hukum adat? Bagaimana persoalan tersebut terumuskan secara jelas, tegas dan adil dalam peraturan perundangundangan sehingga dapat dijadikan acuan?

Tulisan ini mengemukakan konsepkonsep yang mendasari kedudukan dan pola hubungan ketatanegaraan antara Negara Pemerintah dengan masyarakat hukum adat, Beberapa pembatasan dalam tulisan ini adalah: tolok. ukur mempunyai arti keseimbangan atau kesepadanan. Tolok ukur eksistensi hak ulayat atas tanah menurut UUD 45. dan terjabarkan dalam peraturan perundang-undangan dimaksudkan sebagai kesepadanan atau kepantasan suatu pengaturan tentang sesuatu yakni masyarakat hukum adat umumnya dan hak ulayat atas tanah khususnya. Hal ini sesuai dengan doktrin bahwa suatu peraturan perundang-undangan haruslah mencerminkan suatu tujuan filosofis yang menjadi dasarnya, dapat diterima masyarakat karena mengandung nilai keadilan serta secara tegas dan jelas memberikan kepastian hukum. Hak ulayat atas tanah terbatas pada lingkup hak atas tanah dalam lingkungan masyarakat adat saja.

\section{Masyarakat Hukum Adat dan Daya Topang Hak Ulayat atas Tanah}

Bagian terbesar masyarakat di Indonesia hidup dalam komunitas-komunitas struktur sosial budaya tradisional dan sederhana. Ciri masyarakat tersebut menurut Selo Soemarjan adalah:

1. Organisasi sosial didasarkan pada adatistiadat yang terbentuk menurut tradisi,

2. Hukum yang berlaku tidak tertulis, tidak bersifat kompleks,

3. Ekonominya sebagian besar berorientasi untuk kebutuhan sendiri, dan

4. Kegiatan sosial ekonomi memerlukan banyak orang dilakukan secara gotongroyong.

Komunitas masyarakat itu merupakan satuan-satuan masyarakat yang hidup dengan wilayah serta tatanan hukum tersendiri, disebut sebagai satuan masyarakat hukum adat. Hazairin menguraikan lebih lanjut sebagai berikut:2

"Masyarakat-masyarakat hukum adat seperti desa di Jawa, marga di Sumatera Selatan, Nagari di Minangkabau, kuria di Tapanuli, wanua di Sulawesi Selatan adalah kesatuan-kesatuan kemasyarakatan yang mempunyai kelengkapan-kelengkapan untuk sanggup berdiri sendiri, yaitu mempunyai kesatuan hukum, kesatuan penguasa dan kesatuan lingkungan hidup berdasarkan hak bersama atas tanah dan air bagi semua anggotanya. Bentuk hukum kekeluargaannya mempengaruhi

${ }^{2}$ Hazairin, Demokrasi Pancasila, (Jakarta: Penerbit PT Bina Aksara, Tt), hlm. 70. 
sistem pemerintahannya dan sistem umum kemasyarakatannya. Sistem perekonomiannya terutama berlandaskan atas pertanian, petemakan, perikanan dan pemungutan hasil hutan dan hasil air, ditambah dengan sedikit perburuan binatang liar, pertambangan, kerajinan tangan. Semua anggotanya sama dalam hak dan kewajibannya".

Selanjutnya mengenai peran Kepala Adat, Hazairin mengemukakan: ${ }^{3}$

"...Kepala-kepala adat bertugas di semua bidang, menangkap, memeriksa, menghukum, mengampunkan, memberikan syarat-syarat untuk kebebasan..." Hukum adat yang dijalankan oleh kepala-kepala adat adalah hukum yang tradisional, yang turun-temurun dari nenek moyang, yang dimodelir menurut perkembangan zaman'.

Masyarakat adat demikian itu merupakan masyarakat asli bangsa indonesia. Keberadaannya telah ada bersamaan dengan adanya kehidupan kelompok-kelompok masyarakat. Keterbatasan budaya, berakibat tingginya pengaruh ketergantungan dengan lingkungan alam maupun keanggotaan komunitasnya.

Dalam lingkungan masyarakat adat, tanah merupakan tempat utama bertumpunya berbagai kehidupan anggota masyarakat. Tanah sebagai sumber penghidupan anggota masyarakat adat, masyarakat luar wilayah adat, sebagai tempat diselenggarakannya kepentingan umum masyarakat, serta sebagai sumber pendapatan kepala persekutuan hukum adat. Menurut Boedi Harsono, tanah dalam masyarakat adat dapat dipakai sebagai sumber hak-hak perseorangan atas tanah baik hak pakai maupun hak milik. ${ }^{4}$ Tanah dalam lingkungan hukum adat itu sering disebut dengan istilah tanah hak ulayat (ulayat = wilayah).

Di berbagai tempat, tanah hak ulayat mempunyai nama-namanya sendiri. Di Ambon disebut Pertuanan, di Kalimantan disebut Panyampeto, di Bali Prabumian, Payar, di Sulawesi Selatan disebut Limpo, di Minangkabau disebut Ulayat dan di Jawa disebut Wewengkon. Tanah ulayat mempunyai kekuatan berlaku ke dalam dan ke luar. Ke dalam para anggota masyarakat mengatur bagaimana tanah dapat dibagi untuk. berbagai kebutuhan perseorangan dengan memenuhi hak-haknya sebagai warga masyarakat. Tanah dibagi pula untuk kepentingan sosial kemasyarakatan, sedangkan ke luar, tanah dipertahankan dari campur tangan dan dijaga dari pelanggaran oleh orang asing, kecuali dengan ijin ketua adat. Hubungan hak ulayat dengan warga masyarakat hukum adat bersifat kesatuan. Seluruh warga bertanggungjawab atas tanah. Secara analitis ciri khas dari hak ulayat adalah bahwa hubungan antara hak ulayat dengan hak orang perorang bersifat menguncupmengembang bertimbal-balik tiada hentinya. Makin kuat hak perseorangan makin lemahlah hak-hak kemasyarakatan. Dalam lingkungan masyarakat adat, tanah ulayat merupakan

3lbid., hlm. 72.

${ }^{4}$ Boedi Harsono, Hukum Agrania Indonesia, Bagian Pertama Jilid 1, (Jakarta: Djambatan, Tt).. 
conditio sine qua non eksistensi keberadaan masyarakat hukum adat itu sendiri.

Faham Demokrasi dan Negara Hukum sebagai Norma Dasar Eksistensi Hak Ulayat atas Tanah

Dalam pelaksanaan hidup bernegara dan bermasyarakat, menurut UUD 45 Republik Indonesia adalah negara penganut faham demokrasi. Hal itu seperti tercantum dalam Pasal 1 ayat (2) UUD 45 yang menyatakan bahwa. Indonesia adalah Negara berkedaulatan rakyat. Demokrasi mengandung - arti pemerintahan dari rakyat, oleh rakyat dan untuk rakyat (from the people, by the people, and for the people). Istilah demokrasi berasal dari bahasa Yunani, yaitu demos dan cratein. Demos berarti rakyat, cratein berarti memerintah, dan cratos pemerintahan. Secara etimologi demokrasi berarti pemerintahan oleh rakyat, maksudnya suatu pemerintahan yang dilakukan oleh rakyat. Dengan perkataan lain rakyat memegang peranan dalam pelaksanaan pemerintahan. Istilah ini semula dipakai di Yunani Kuno, khususnya Athena, untuk menyebutkan suatu sistem pemerintahan di Negara Kota di sana. Pada waktu penduduk negara kota hanya sedikit dan memungkinkan seluruh warga kota ikut langsung merundingkan masalah kehidupan negaranya bersama-sama dalam waktu tertentu. Dengan demikian, seluruh warga kota ikut secara aktif menentukan kebijakan politik yang akan dilaksanakan oleh para pemimpin negara kota tersebut. Berbagai pengertian demokrasi dikemukakan oleh beberapa orang ahli sebagai berikut:

1) Lincoln menyatakan bahwa demokrasi is the government of the people, by the people and for the people. ${ }^{5}$

2) Logemann menyatakan, bahwa the formal democracy is indicating a method of organizing authority. Substantial democracy is normative, accepting a nom, $i, e$, a value judgement claiming validity and this validity is an absolute concept of the human personality. Any society in which a given personality evalution prevails will wish that this evalution shall find expression in the political organization of the particular society. ${ }^{6}$

3) SM Lipset menyatakan bahwa Democracy in a complex society may be defined as a political system which supplies regular contitutional opportunities for changing the governing officials and a social mechanism which permits the largest possible part of the population to influence major decision by choosing contenders for political office. $^{7}$

4) Dalam Dictionary of Sociology, demokrasi diartikan sebagai a philosophy, or a social system, that stresses participation in and proportional control of, the affairs of the community by the human being, regardless of his qualities, ranks, status or possession. ${ }^{8}$

sWilliam Ebenstein, American Democracy in Word Perspective (New York: Harper \& Row Publiser 1970), him. 73.

¿Logemann dalam bukunya Harold Stein, Public Administration and Public Policy (Boston: LitteBrown, 1969).

${ }^{7}$ Lipset S.M. Political Man (New York: Harper \& Row Publisher, 1960).

'Tumer, Henry A, Dictionary of Sociology (Boston: Little Brown, 1989). 
5) Dardji Darmodihardjo berpendapat, bahwa demokrasi adalah pemerintahan oleh rakyat, yang berarti rakyat memegang peranan dalam melaksanakan pemerintahan. ${ }^{9}$

Bertumpu dari tinjauan pustaka tersebut dapatlah dikemukakan bawa demokrasi merupakan asas yang mengandung unsurunsur:

1) Pemerintahan dari rakyat, oleh rakyat dan untuk rakyat yang berarti rakyat ikut serta dalam pemerintahan.

2) Pelaksanaan pemerintahan oleh rakyat tersebut dapat dilaksanakan secara langsung maupun tidak langsung (melalui perwakilan).

3) Rakyat aktif ikut serta menentukan jalannya pemerintahan.

Demokrasi dengan unsur-unsur tersebut di atas haruslah terlaksana dalam fungsi pemerintahan. Dalam hubungan ini Koentjoro Poerbopranoto menyatakan bahwa dalam pelaksanaan demokrasi, terjadi pelaksanaan fungsi pemerintahan, yang dalam segala aspeknya rakyat ikut berperan secara aktif, baik secara langsung maupun melalui lembaga perwakilannya. Fungsi pemerintahan terdiri dari fungsi memerintah dan fungsi melayani. Dalam hal ini Hazairin menambahkan bahwa pelaksanaan demokrasi dalam fungsi pemerintahan berarti pula rakyat ikut serta mengawasi jalannya pemerintahan berdasarkan norma hukum dan norma agama." Pendapat senada berkenaan dengan pelaksanaan demokrasi di Indonesia dikemukakan oleh Sri Soemantri, ${ }^{2}$ yang berpendapat, bahwa pelaksanaan demokrasi Pancasila hakikatnya kerakyatan yang dipimpin oleh hikmah kebijaksanaan dalam permusyawaratan/perwakilan, yang disemangati oleh Ke-Tuhanan Yang Maha Esa, kemanusiaan yang adil dan beradab, persatuan Indonesia dan keadilan sosial bagi seluruh rakyat Indonesia.

Dalam UUD 45 baik pada pembukaan maupun beberapa pasal batang tubuhnya menegaskan bahwa negara İndonesia adalah Negara demokrasi. Alinea ke empat Pembukaan UUD 45 dinyatakan bahwa Negara Republik Indonesia adalah Negara yang berkedaulatan rakyat berdasarkan: $\mathrm{Ke}$ Tuhanan Yang Maha Esa, kemanusiaan yang adil dan beradab, persatuan Indonesia, kerakyatan yang dipimpin oleh hikmat kebijaksanaan dalam permusyawaratan/ perwakilan serta dengan mewujudkan suatu keadilan social bagi seluruh rakyat Indonesia. Pasal 1 ayat (2) menyatakan bahwa kedaulatan adalah di tangan rakyat dan dilakukan sepenuhnya oleh Majelis Permusyawaratan Rakyat. Pasal 5 ayat (1) menyatakan bahwa Presiden memegang kekuasaan membentuk

๑Dardji Darmodihardjo dan Nyoman Dekker, Pokok-pokok Demokrasi Pancasila (Malang:Penerbit Universitas Brawijaya, 1979), hlm. 15.

${ }^{10}$ Koentjoro Poerboprawoto, Sedikit Tentang Sistem Demokrasi (Surabaya: Penerbit Universitas Airlangga, Surabaya, 1956), hlm. 121.

"Hazairin, Demokrasi Pancasila (Jakarta: Penerbit PT. Bina Aksara, 1985), him. 81.

${ }^{12}$ Sri Soemantri, 1992, Bunga Rampai Hukum Tata Negara Indonesia (Bandung:Alumni, 1992), hlm. 19. 
undang-undang dengan persetujuan Dewan Perwakilan Rakyat. Pasal 20 ayat (1) menyatakan bahwa tiap-tiap undang-undang menghendaki persetujuan Dewan Perwakilan Rakyat. Pasal 21 ayat (1) menyatakan bahwa anggota Dewan Perwakilan Rakyat berhak mengajukan rancangan Undang-Undang. Dalam Penjelasan umum angka II tentang Pokok-pokok Pikiran Pembukaan, khususnya dalam pokok pikiran ketiga dinyatakan sebagai berikut:

"Pokok yang ketiga yang terkandung dalam' "Pembukaan" ialah Negara yang berkedaulatan rakyat, berdasarkan atas kerakyatan dan permusyawaratan perwakilan. Oleh karena itu, sistem Negara yang terbentuk dalam UndangUndang Dasar harus berdasar atas kedaulatan rakyat dan berdasar permusyawaratan perwakilan.

Memang aliran ini sesuai dengan sifat masyarakat Indonesia".

Dari beberapa pendapat dan ketentuanketentuan di atas dapatlah dikemukakan unsur-unsur pelaksanaan asas demokrasi di Indonesia sebagai berikut:

1) Rakyat yang memegang kedaulatan, berarti rakyat ikut serta dalam pelaksanaan fungsi pemerintahan.

2) Keikutsertaan rakyat ini dilakukan secara tidak langsung, yakni melalui lembaga perwakilannya, baik yang berbentuk MPR maupun DPR. Rakyat melalui lembaga perwakilannya berhak mengawasi jalannya pemerintahan.

Demokrasi yang berintikan kedaulatan rakyat itu berkenaan dengan pelaksanaan fungsi pemerintahan -pemencaran kekuasaan dan keterlibatan rakyat delam pelaksanaan fungsi pemerintahan tersebut, di dalamnya tersirat suatu asas penting yakni asas kebebasan sebagai karakteristik dari kedaulatan rakyat dan asas penghargaan menentukan pilihan jalan hidup. Dalam hubungan ini Muhammad Hatta menyatakan: ${ }^{13}$

"Menurut dasar kedaulatan rakyat itu, hak rakyat untuk menentukan nasibnya tidak hanya ada pada pucuk pemerintahan negeri, melainkan juga pada tiap tempat, di kota, di desa dan di daerah. Tiap-tiap golongan persekutuan itu mempunyai badan perwakilan sendiri, seperti Gemeenteraad, Provinciale Raad dan lainlainnya. Dengan keadaan demikian, maka tiap-tiap bagian atau golongan rakyat mendapat otonomi (membuat dan menjalankan peraturan sendiri) dan zelfbestuur (menjalankan peraturanperaturan yang dibuat oleh Dewan yang lebih tinggi). Jadinya bukan saja persekutuan yang besar, rakyat semuanya, mempunyai hak untuk menentukan nasibnya sendiri, melainkan juga tiap-tiap bagian dari negeri atau bagian dari rakyat yang banyak. Keadaan yang seperti itu penting sekali, karena keperluan tiap-tiap tempat dalam suatu negeri tidak sama, melainkan berlain-Jain".

\footnotetext{
${ }^{13}$ Mohammad Hatta, Ke arah Indonesia Merdeka, dalam kumpulan karangan Jilid 1, (Jakarta: Bulan Bintang, 1932), him. 103.
} 
Dalam karangan yang sama beliau menyatakan: ${ }^{14}$

"Oleh karena Indonesia terbagi atas beberapa pulau dan golongan bangsa, maka perlulah tiap-tiap golongan, kecil atau besar, mendapat otonomi, mendapat hak untuk menentukan nasibnya sendiri. Satu-satunya dapat mengatur pemerintahan sendiri menurut keperiuan dan keyakinan sendiri, asal saja peraturan-peraturan masing-masing tidak berlawanan dengan dasar-dasar pemerintahan umum".

S.E. Finer menyebutkan tiga asumsi kedaulatan rakyat yaitu: ${ }^{15}$

1) Pemerintahan berkedaulatan rakyat adalah pemerintahan yang memiliki kekuasaan terbatas atau dibatasi.

2) Pemerintahan berkedaulatan rakyat adalah pemerintahan yang mengakui kemajemukan masyarakat.

3) Pemerintahan berkedaulatan rakyat menolak adanya setiap upaya untuk memutlakkan suatu pandangan atau pikiran mengenai masyarakat dan moral. Sikap ini antara lain akan diwujudkan dengan toleransi dalam kehidupan bernegara dan bermasyarakat.

Secara analogi meminjam pendapat Robert Rienow ${ }^{16}$ tentang alasan penting dibentuknya pemerintahan tingkat daerah menyatakan:
Pertama: "that a democratic people shoild form the habit of deciding of public matters that directly affect them.

Kedua: That different requirements of the various communities can be satisfied only by letting each make the rules and lay the plans for own govemance".

Dari pendapat tersebut dapat dikemukakan bahwa dalam konsep demokrasi terkandung:

1) Nilai untuk mewujudkan kebebasan;

2) Nilai agar rakyat menentukan sendiri berbagai kebutuhannya;

3) Nilai untuk mengurus serta mengatur hidup oleh dininya sendiri;

4) Nilai untuk memberikan pelayanan sebaik-baiknya pada rakyat walau dengan tuntutan yang berbeda.

Dengan demikian eksistensi sistem sosial budaya masyarakat adat sudah semestinya dihargai sebagai wujud penghormatan akan harkat dan martabat golongan masyarakat berdasarkan asas kebebasan untuk menentukan pilihan hidup dan mengatur jalan hidupnya.

Dalam pada itu, paham kedaulatan rakyat/ demokrasi berkaitan erat dengan unsur negara hukum di mana diasumsikan bahwa nilai-nilai. demokratis tercermin secara normatif dalam sistem peraturan perundang-undangannya. Menurut paham klasik, negara hukum mempunyai ciri-ciri sebagai berikut:

14/bid.

15S.E. Finer, Comparativ Govemment (London:Pinguin, 1978), hlm. 64-65.

${ }^{16}$ Robert Rienow, Introduction Govemment $3 \mathrm{~d}$ Edn, (New York: Alfred A Knoof, Tt), hlm. 573. 
2) Adanya pembagian kekuasaan dan secara khusus menjamin suatu kekuasaan kehakiman yang merdeka;

3) Adanya pemencaran kekuasaan;

4) Adanya jaminan terhadap hak asasi manusia;

5) Adanya jaminan persamaan di muka hukum dan jaminan perlindungan hukum;

6) Adanya asas legalitas yang menyatakan bahwa seluruh tindakan pemerintah harus berdasarkan atas hukum (undangundang).

Berbagai unsur negara hukum tersebut pertama-tama mengandung makna membatasi kekuasaan pemerintah atau negara. Undang-undang dasar sebagai perwujudan paham konstitusi dibuat dalam rangka membatasi kekuasaan pemerintah atau negara. Dalam hubungan ini Sri Soemantri menyatakan: ${ }^{17}$

"Dengan demikian, konstitusi atau undang-undang dasar merupakan alat untuk membatasi kekuasaan dalam negara. Bahwa konstitusi atau undangundang dasar pada hakikatnya merupakan pembatasan kekuasaan dalam negara dapat dibuktikan dari materi muatan yang selalu terdapat dan diatur di dalamnya".

Dalam penjelasan tentang Sistem Pemerintahan Negara dinyatakan secara tegas bahwa Indonesia merupakan suatu negara hukum. Penjelasan tersebut antara lain:

a) Indonesia adalah Negara yang berdasarkan atas hukum (rechtstaat).

b) Negara Indonesia berdasarkan atas hukum (rechtsstaat tidak berdasarkan atas kekuasaan belaka (machtstaat).

c) Pemerintah berdasarkan atas sistem konstitusi (hukum, dasar), tidak bersifat absolutisme (kekuasaan yang tidak terbatas).

Berkaitan dengan prinsip demokrasi dan negara hukum, maka pemencaran kekuasaan dan penghargaan atas hak-hak masyarakat hukum adat bertujuan untuk membatasi kekuasaan negara atau pemerintah. Penyerahan atau membiarkan atau mengakui berbagai urusan pemerintahan dan kemasyarakatan diatur dan diurus sendiri, mengandung arti pusat tidak lagi mengatur urusan yang telah ada.

"Kita tidak mungkin menyeragamkan kebutuhan-kebutuhan daerah yang memang berbeda-beda itu dengan tiada memperkosa kebutuhan-kebutuhan itu sendiri. Dasar negara kesatuan tidak boleh diartikan, bahwa perkembangan yang dalam kodrat aslinya memang berbeda sifatnya, lalu harus disamaratakan dengan paksa, akan tetapi kebebasan itu pun tidak boleh dipertahankan demikian rupa sehingga menyalahi atau memperkecil sistem persatuan". ${ }^{18}$

${ }^{17}$ Sri Somantri, Ketetapan MPR(S) sebagai salah satu sumber Hukum Tata Negara, (Bandung: Remaja Karya, 1988), hlm. 2.

${ }^{18}$ Soemarto, Susunan Negara Kita, (Jakarta: Djambatan, 1955), hlm. 1-2. 
Jaminan hak asasi manusia, persamaan di muka hukum, perlindungan hukum dan asas legalitas bertujuan untuk menghindarkan negara atau pemerintah bertindak sewenangwenang. Perbuatan atau tindakan negara atau pemerintah tidak boleh melampaui atau melanggar hak asasi manusia, termasuk hak hidup suatu komunitas masyarakat hukum adat tidak boleh menyebabkan seseorang atau sekelompok orang tidak mendapat perlindungan hukum sebagaimana mestinya, tidak boleh membeda-bedakan orang karena alasan yang tidak sah dan semua perbuatan atau tindakan pemerintah harus berdasar pada ketentuan. (hukum) yang berlaku.

Konsepsi kerakyatan yang mengedepankan pula paham adanya perbedaan dan jalan untuk menentukan pilihan hidupnya masing-masing harus secara tegas tercermin dalam suatu peraturan perundang-undangan sebagai bentuk manifestasi atau bagian yang tidak dapat dipisahkan dari konsepsi negara hukum. Begitu pula sebaliknya, sehingga suatu negara semacam itu disebut negara hukum demokratis.

\section{Hak Ulayat dalam Peraturan}

\section{Perundang-undangan}

Landasan konstitusional eksistensi masyarakat hukum adat terdapat dalam Perubahan Kedua UUD 45 Pasal 18 B ayat (2). Pasal tersebut menyatakan:

“(2) Negara mengakui dan menghormati kesatuan-kesatuan masyarakat hukum adat beserta hak-hak tradisionalnya sepanjang masih hidup dan sesuai dengan perkembangan masyarakat dan prinsip Negara Kesatuan Republik Indonesia yang diatur dalam undang-undang".
Semangat yang menjiwai tambahan pasal perubahan UUD 45 tersebut adalah semangat untuk meletakkan secara proporsional harkat dan martabat suatu golongan masyarakat untuk menentukan jalan hidupnya sendiri dalam kerangka kehidupan berbangsa dan bernegara. Penyamarataan terhadap unsurunsur politik, sosial dan budaya suatu kelompok masyarakat sama dengan pengebirian suatu kelompok masyarakat itu sendiri dan sama dengan perendahan suatu martabat kelompok masyarakat. Hal demikian merupakan penormaan yang bertentangan dengan nilai demokrasi yang sedang dikembangkan.

Pengakuan terhadap eksistensi suatu kelompok masyarakat adat secara implisit mengandung arti pengakuan terhadap hak ulayat atas tanah. Hal ini dilihat dari kedudukan hak ulayat atas tanah sebagai unsur utama penopang eksistensi suatu kesatuan masyarakat hukum adat. Dengan demikian, adanya hak ulayat atas tanah merupakan conditio sine qua non dari keberadaan masyarakat hukum adat itu sendiri, sehingga hak ulayat masyarakat hukum adat tidaklah dapat dihapuskan oleh kepentingan lain selain kepentingan masyarakat hukum adat itu sendiri. Dasar pemikiran demikian seharusnya secara eksplisit tertuang dalam UUPA sehingga UUPA di samping dimaksudkan sebagai payung hukum dalam pengaturan masalah agraria, juga secara praktis dapat memberikan jaminan perlindungan hukum bagi berbagai golongan masyarakat khususnya golongan ekonomi lemah atas akses sumber daya alam, khususnya tanah. Sayangnya politik agraria yang demikian mulia tidak dipahami secara utuh dan ditindaklanjuti oleh pemerintah, terbukti dengan banyaknya peraturan yang 
belum ada dan peraturan yang ada pun banyak tidak sinkron satu dengan lainnya.

Berbagai peraturan yang memposisikan tanah ulayat demikian itu nampak daiam UUPA maupun peraturan lainnya. Pertama, Pasal 2 ayat (2) dan (4) Peraturan Dasar Pokok-pokok Agraria (selanjutnya disebut UUPA) dinyatakan bahwa hak ulayat diakui keberadaannya. Namun menurut Pasal 3 eksistensinya dibatasi sepanjang kenyataannya masih ada dan pelaksanaannya harus sesuai dengan kepentingan nasional dan negara serta tidak bertentangan dengan peraturan perundangundangan yang lebih tinggi. ${ }^{19}$ Pembatasan demikian cenderung mengebiri eksistensi masyarakat hukum adat, sebab walaupun masyarakat hukum adat masih ada, dan hak. ulayat dibutuhkan sebagai penopang hidupnya, namun jika pemenintah memerlukan tanah ulayatnya, maka tanah hak ulayat tersebut dapat diminta atau dihapuskan. Politik hukum demikian juga mengakibatkan kegamangan banyaknya pihak yang berkepentingan dengan mengatasnamakan pemerintah. Kedua, dalam memori penjelasan angka II/3 UUPA dinyatakan bahwa hak ulayat termasuk dalam lingkup tanah negara, yakni tanah yang dikuasai langsung oleh negara. Dalam kedudukannya sebagai tanah negara menurut Pasal 28 ayat (1). UUPA, maka hak ulayat dapat dimasukkan menjadi objek hak guna usaha. Peraturan ini seolah-olah melengkapi peraturan di atas. Visi pemerintah yang seharusnya mengedepankan penghormatan atas harkat dan martabat masyarakat adat berubah menjadi visi yang mengedepankan pembangunan fisik dan menjadikan sumber daya alam termasuk tanah sebagai obyek pembangunan yang harus mempunyai arti secara ekonomis. Lemahnya penghargaan terhadap eksistensi masyarakat hukum adat serta ketiadaan data mengenai jumlah kelompok masyarakat adat dan luas tanah hak ulayatnya menjadikan tanah hak ulayat yang sebagian besar berada di wilayah hutan dijadikan objek konsesi

${ }^{19}$ Selengkapnya Pasal 2 ayat (2) dan (4) serta Pasal 3 berbunyi:

Pasal 2 ayat (2) "Hak menguasai dari Negara termasuk dalam ayat (1) memberi wewenang untuk:

a. Mengatur dan menyelenggarakan peruntukan, penggunaan, persediaan dan pemeliharaan bumi, air dan ruang angkasa tersebut.

b. Menentukan dn mengatur hubungan-hubungan hukum antara orang-orang dengan bumi, air dan ruang angkasa.

c. Menentukan danmengatur hubungan-hubungan hukum antara orang-orang dan perbuatan-perbuatan hukum yang mengenai bumi, air dan ruang angkasa".

Ayat (4) "Hak menguasai Negara pelaksanaannya dapat dikuasakan kepada Daerah-daerah Swatantra dan masyarakat-masyarakat hukum adat, sekedar diperlukan dan tidak bertentangan dengan kepentingan Nasional, menurut ketentuan-ketentuan Peraturan Pemerintah".

Pasal 3 "Dengan mengingat ketentuan-ketentuan dalam pasal 1 ayat (2) pelaksanaan hak ulayat dan hak-hak yang serupa itu dari masyarakat-masyarakat hukum adat, sepanjang menunut kenyataannya masih ada harus sedemikian rupa sehingga sesuai dengan kepentingan Nassional dan Negara yang berdasarkan atas persatuan Bangsa serta tidak boleh bertentangan dengan undang-undang dan peraturan-peraturan lain yang lebih tinggir. 
dengan hak guna usaha oleh pihak swasta. Tidak mustahil usaha-usaha masyarakat hukum adat di tanah ulayatnya dikategorikan sebagai penambang liar atau perambah hutan liar. Kasus-kasus yang terjadi menggambarkan keadaan tersebut. Di Jawa Barat saja masih terdapat lebih dari 26.000 ha hutan yang diklaim sebagai hutan lindung milik Departemen Kehutanan ternyata masih dikuasai oleh penduduk setempat yang mendasarkan pada tanah ulayat. Demikian pula konflik lain seperti di Desa Cimaraewah dan Gunungherang Kecamatan Cikalong, Kabupaten Bandung, sekelompok petani setempat memperebutkan 400 ha lahan kehutanan, demikian pula kasus desa Cisewu Kabupaten Garut dan kawasan Gunung Gede Pangrango Jawa Barat. ${ }^{20}$ Berdasarkan penelitian yang dilakukan oleh Mahkamah Agung Republik Indonesia dan Universitas Dharma Agung Medan, khususnya di Propinsi Sumatera Barat (kecuali kota Padang) dan Propinsi Jambi dapat diperoleh gambaran sebagai berikut:21

a) Kantor Pertanahan setempat berdasarkan Peraturan Pemerintah Nomor 10 Tahun 1961 ternyata belum melakukan pendaftaran atas tanah hak ulayat atas tanah, padahal Ninik mamak sebagai penguasa atas tanah ulayat menurut peraturan pemerintah tersebut merupakan subjek pemegang hak ulayat. b) Dalam perkembangan banyak tanah hak ulayat yang dijadikan objek hak guna usaha sehingga menimbulkan konflik kepentingan antara pemegang konsesi hak pengelolaan hutan dengan masyarakat adat setempat.

c) Tanah-tanah hak ulayat yang diberikan kepada perseorangan maupun badanbadan diberikan status sebagai hak milik dan hak pakai menurut konsepsi UUPA, dalam kenyataannya sukar diminta kembali oleh masyarakat adat setempat walaupun tanah tersebut diterlantarkan atau hak pakainya telah habis.

d) Berdasarkan Peraturan Pemerintah Nomor 24 Tahun 1997 Ninik mamak tidak lagi berkedudukan sebagai subjek penguasa pemegang hak ulayat masyarakat hukum adat. Ketentuan ini menimbulkan banyak protes di kalangan Ninik mamak karena dianggap tidak menghargai lagi adanya peran ketua adat dan hak ulayat atas tanah.

Ketimpangan kedua ketentuan hukum tersebut terasa lebih sempurna dengan ketentuan Pasal 2 Undang-Undang Nomor 37 Prp - Tahun 1960 jo Undang-Undang Nomor 11 Tahun 1967 tentang Pertambangan Minyak dan Gas Bumi. Pasal tersebut menyatakan bahwa segala bahan galian adalah kekayaan nasional dan dikuasai oleh Negara. Dalam memori Penjelasannya dinyatakan bahwa 1994).

${ }^{20}$ Endang Suhendar, Pemetaan Pola-pola Sengketa Tanah di Jawa Barat (Bandung: Yayasan Akta Tiga,

${ }^{21}$ "Eksistensi Hak Ulayat di Sumatra Barat dan Jambi", Artikel Majalah Bhumi Bhakti, Media Komunikasi Pertanahan, Edisi ke 22 Th. (2000), him. 36-41. 
dikuasai artinya Negara menguasai sepenuhnya bahan galian tersebut. Demikian pula Pasal 5 ayat (1) Undang-Undang Nomor 5 Tahun 1967 tentang Pokok-Pokok Kehutanan dinyatakan bahwa semua hutan dalam wilayah Republik Indonesia termasuk kekayaan alam yang terkandung di dalamnya dikuasai oleh Negara.

\section{Beberapa Tolok Ukur Eksistensi Hak Ulayat atas Tanah}

Pemerintah dan rakyat Indonesia dalam alam demokrasi sekarang ini telah menegaskan suatu paradigma baru tentang perlunya penghargaan atas eksistensi masyarakat hukum adat sebagai bagian dari pelaksanaan prinsip demokrasi. Paradigma tersebut perlu dijabarkan dalam suatu kaidah normatif agar dapat dijadikan pedoman sikap tindak administrasi negara. Dalam pandangan demikian, eksistensi suatu masyarakat hukum adat tidak dapat ditentukan oleh institusi lain selain masyarakat hukum adat itu sendiri. Pendeknya tidak ada satu pun institusi yang merasa mempunyai wewenang untuk menentukan ada tidaknya suatu komunitas masyarakat hukum adat. Namun demikian, dapat dilakukan suatu pedoman-pedoman umum tentang apa dan bagaimana suatu masyarakat hukum adat itu. Pedoman demikian penting untuk dijadikan pinjakan bertindak. Pedoman itu dapat dibuat oleh suatu lembaga musyawarah adat dalam lingkup wilayah kabupaten setempat sebagai badan otonom yang dibentuk berdasarkan suatu peraturan daerah. Keanggotaan badan musyawaah adat tediri dari para tokoh masyarakat adat setempat. Tugas utama badan tersebut adalah memberikan pertimbangan kepada pemerintah daerah khususnya berkaitan dengan penerapan kebijakan pemerintah daerah yang berdampak pada masyarakat adat setempat.

Sebagaimana dikemukakan bahwa tanah hak ulayat berfungsi sebagai daya topang utama kehidupan masyarakat adat. Oleh karena itu jika terdapat suatu komunitas masyarakat adat, maka keberadaan tanah hak ulayat tersebut melekat dengan keberadaan masyarakàt hukum adat itu sendiri. Dalam konsepsi demikian semestinya tidak boleh terdapat suatu peraturan perundangundangan yang dapat menghapuskan atau mengeliminer tanah hak ulayat. Sebaliknya ditetapkan secara jelas dan tegas dalam batasbatas manakah tanàh hak ulayat tersebut berada. Mencari Iuasan tanah hak ulayat tidaklah mudah mengingat masih terdapat sifat nomaden suatu komunitas masyarakat adat, namun jika dilihat dari tujuan yang hendak dicapai masyarakat hukum adat atas tanahnya yakni terpenuhinya kebutuhan hidup, maka melalui berbagai usaha penyuluhan khususnya tentang pemanfaatan sumber daya alam (tanah) kiranya penetapan batas luas tanah hak ulayat dapat tercapai.

Persoalan lain adalah perihal jenis hak yang akan diberikan dan kewenangan apa saja yang dapat diberikan kepada masyarakat hukum adat atas tanah ulayatnya? Hal ini dikembalikan kepada kemampuan masyarakat hukum adat itu sendiri. Alasan yang melatarbelakangi adalah sifat perkembangan masyarakat adat yang satu yang satu sama lain berbeda bahkan pola hubungan keterikatan antara individu anggota masyarakat adat dengan kelompoknya dapat menguncup dan mengembang yang berakibat pemecahan hak-hak atas tanah. 
Dalam hal ini mengingat peran para ketua adat yang dominan maka kewenangan yang diberikan adalah jenis kewenangan untuk mengatur perencanaan dan penggunaan atas tanah wilayahnya, termasuk dalam hal ini adalah kewenangan untuk mengatur hubungan-hubungan hukum antar anggota, anggota dengan komunitasnya serta antara komunitas dengan pihak asing. Batasan pemanfaatan tanah adalah sepanjang pengelolaan tanah termasuk apa yang ada di atas tanah serta di dalam tanah dalam batasbatas tertentu bermanfaat untuk kepentingan masyarakat adat dan anggotanya. Dengan demikian tanaman dan hasilnya haruslah menjadi hak masyarakat adat. Demikian pula bahan galian yang sekiranya mampu dikelola seperti jenis galian $\mathrm{C}$ dapatlah dijadikan hak masyarakat adat.

Pada masyarakat hukum adat, hak atas tanah yang sekiranya tepat adalah hak pengelolaan atas tanah. Hak tersebut merupakan bagian dari pelimpahan kekuasaan Negara atas tanah yang pelaksanaannya diberikan kepada masyarakat hukum adat. Pemegang hak pengelolaan dapat secara leluasa menetapkan adanya hak-hak baru seperti hak pakai, hak sewa, hak bagi hasil bahkan jika mungkin menjadi hak milik. Tanah dengan status hak pengelolaan tersebut harus terdaftar sebagai objek tanah yang dipunyai suatu badan hukum dengan diberikan penegasan tentang batas-batas tanahnya sehingga kuat terhadap tuntutan atau gangguan pihak lain. Apabila kepentingan umum yang lebih luas menghendaki atas tanah tersebut, jalan yang ditempuh adalah dengan cara mengganti dengan tanah lain atau dengan cara penyertaan modal (berupa tanah) untuk dipergunakan sebagai obyek kepentingan umum yang dimaksud.

\section{Simpulan}

Demokrasi sangat menjunjung tinggi prinsip penghormatan tentang eksistensi masyarakat hukum adat pada umumnya dan hak ulayat atas tanah khususnya. Prinsip tersebut harus terjabarkan secara tegas dalam peraturan perundang-undangan agar tidak terjadi kesewenang-wenangan terhadap masyarakat hukum adat. Pemerintah, khususnya pemerintah daerah kiranya perlu ragu-ragu untuk memberikan suatu hak atas tanah ulayat dalam bentuk yang terdaftar sehingga terhindar dari objek konsesi hak pengelolaan hutan oleh pihak swasta. Pemerintah daerah juga harus berani mempelopori pembentukan lembaga musyawarah adat sebagai mitra dan mencari solusi yang menguntungkan bersama manakala kepentingan umum atas tanah ulayat terpaksa dijadikan objek pembangunan. $\square$

\section{Daftar Pustaka}

Amrah Muslimin. Aspek-aspek Hukum Otonomi Daerah, 1903-1978. Bandung: Alumni, 1978.

Bagir Manan dan Kuntana Magnar. 1993. Beberapa Masalah Hukum Tatanegara Indonesia. Bandung: Alumni, 1993.

Boedi Harsono. Hukum Agrari Indonesia. Bajgian Pertama. Jitid. Jakarta: Jambatan, 1975.

Bonger. Problema Der Democratie. Kluwer Deventer Nijmegen.TTp:Tp, 1971. 
C Van Vollenhoven. 1925. Het Adatrech Van Nederlands Indie. Jilid 1 bagian 1 tahun. TTp:Tp, 1925.

Darji Darmodihardjo dan Nyoman Dekker. Pokok-pokok Demokrasi Pancasila. Malang: Penerbit Universitas Brawijaya, 1979.

Endang Suhendar. General Theory of Law and State, Russell \& Russell. New York: Tp, 1973.

Hazairin. Demokrasi Pancasila. Jakarta: Penerbit PT Bina Aksara, 1985.

Imam Soetiknyo. Politik Agraria Nasional Hubungan Manusia Dengan Tuhan Yang Berdasarkan Pancasila. Yogyakarta: Gajah Mada Universitas Yogyakarta, 1983.

Koentjoro Poerbopranoto. Sedikit Tentang Sistem Demokrasi. Surabaya: Penerbit Univ ersitas Airlangga, 1956.

Lipset S.M. Political Man. New York: Harper \& Row Publisher, 1960.

Harold Stein. Public Administration and Public Policy. Boston: Little Brown, 1969.

Mohammad Hatta. Ke Arah Indonesia Merdeka, dalam kumpulan karangan, Jilid I, Bulan Bintang, Jakarta, 1976.

Roesbadi Adiwilaga. Hukum Agraria Dalam Teori dan Praktek. Bandung: NV Nusa Baru, 1962.

Selo Soemardjan (Penyunting). Hukum Kenegaraan RI Teori, Tatanan dan Terapan, Kerjasama Yayasan IImu-ilmu Sosial. Jakarta: PT Gramedia Wisiasarana Indonesia, 1993.
Soenarko. Susunan Negara Kita. Jakarta: Jambatan, 1955.

Soerjono Soekanta dan Soleman B. Taneko. Hukum Adat Indonesia. Jakarta: Rajawali, 1981.

S.E. Finer. Comparative Govemment. London: Pinguin, 1978.

Sri Soemantri. Bunga Rampai Hukum Tatanegara Indonesia. Bandung: Alumni, 1992.

Teluki. Perbedaan Hak Milik Atas Tanah dan Recht Van Eigendom. Bandung: PT Eresco, 1966.

Terhaar, B.Bzn. Terjemahan oleh Soebakti Poesponoto, K.NG. Asas-Asas dan Susunan Hukum Adat. Jakarta: Pradnya Paramita, 1981.

Tumer, Henry A.. Dictionary of Sociology. Boston: Little Brown, 1989.

William Ebenstein. American Democracy. In Word Perspective. New York: Harper \& Row Publisher, 1970.

Boedi Harsono. Hukum Agraria Indonesia, Himpunan Peraturan-peraturan Hukum Tanah. Cet. ketigabelas (Edisi Revisi). Jakarta: Jambatan, 1996.

—. UUD, Pedoman Penghayatan dan Pengamalan Pencasila, Garis-Garis Besar Haluan Negara. Jakarta: BP 7 Pusat, 1990.

Ketetapan-Ketetapan MPR 2000 Pada Sidang Tahunan MPR 2000. Jakarta: Sinar Grafika. 